\title{
Diare Sebagai Konsekuensi Buruknya Sanitasi Lingkungan
}

\author{
Ummy Maisarah Rasyidah ${ }^{1 *}$ \\ ${ }^{1}$ Fakultas Kedokteran, Universitas Surabaya, Surabaya-Indonesia \\ * corresponding author:dr.ummy.m.rasyidah@staff.ubaya.ac.id
}

\begin{abstract}
Diarrhea becomes the second disease after ARI that causes morbidityand death in Indonesia. Riskesdas in 2007 shows diarrhea as an infectious disease with high morbidity and mortality rates. The morbidity survey by the Directorate General of Disease Control and Environmental Health of the Ministry of Health from 2000 - 2010 showed a tendency for the incidence of diarrheal disease to rise, namely the 2000 Incidence Rate of diarrheal disease 301/1000 population, in 2003 it rose to 374/1000 population, in 2006 it became $423 / 1000$ residents and in 2010 became 411/1000 residents. This paper wants to find out the preventive actions taken by the government in controlling diarrheal diseases in terms of environmental sanitation. Literature searches are conducted online and manually on scientific publications in Indonesian or English, with keywords in the form of diarrheal disease, environmental sanitation, public health efforts, government and health offices. The results show that from 25 related publications, 17 publications discuss diarrhea and 8 publications discuss environmental sanitation. The conclusion obtained is the incidence of diarrhea fluctuates from year to year. An increase in diarrheal disease is associated with poor environmental sanitation, the root of which is the lack of a wareness and knowledge in particular rural communities to maintain and preserve and carry out healthy living behaviors to break the cycle of diarrheal transmission in Indonesia.
\end{abstract}

Keywords: hygiene, sanitation, diarrhea

Abstrak-Diare menjadi penyakit kedua setelah ISPA yang menyebabkan kejadian kesakitan maupun kematian di Indonesia. Riskes das tahun 2007 menunjukkan diare sebaga i penyakit menular dengan angka morbiditas dan mortalitas yang tinggi. Tulisan ini ingin mengetahui tindakan preventif yang dilakukan pemerintah dalam usaha mengendal ikan terja dinya penyakit diare ditinjau dari sa nitasi lingkungan. Penelusuran literatur dilakukan secara online dan manual terhadap publikasi ilmiah berbahasa Indonesia a tau Inggris, dengan kata kunci berupa penya kit diare, sanitasi lingkungan, usa ha kesehatan masyarakat, pemerintah dan dinas kesehatan. Hasil amatan menunjukkan dari 25 publikasi yang berkaitan, 17 publikasi membahas tentang diare dan 8 publikasi membahas tentang sanitasi lingkungan. Kesimpulan yang didapatkan adalah angka insiden diare berfluktuasi dari tahun ke tahun. Peningkatan penyakit diare berhubungan dengan buruknya sanitasi lingkungan yang akar permasala hannya terdapat pa da kurang kesadaran dan pengetahun pada khususnya masyarakat pedesaan untuk menjaga dan melestarikan serta melakukan perilaku hidup sehat untuk memutuskan siklus rantai penularan penyakit diare di Indonesia.

Kata kunci: higiene, sanitasi, diare

\section{PENDAHULUAN}

Buruknya sanitasi lingkungan membuat tempat berkembang biaknya berbagai macam penyakit dan sebagai penyebab utama penyakit yang timbul dari buruknya kesehatan lingkungan. Contoh penyakit yang timbul dari buruknya kesehatan lingkungan, antara lain infeksi saluran pernapasan akut (ISPA), malaria, demam berdarah, kecacingan, penyakit kulit, TBC dan diare. Riset kesehatan dasar (Riskesdas) tahun 2007 menunjukkan bahwa diare merupakan penyakit menular dengan angka morbiditas dan mortalitas yang masih tinggi. Survei morbiditas yang dilakukan oleh Direktorat Jendral Pengendalian Penyakit dan Penyehatan Lingkungan Departemen Kesehatan dari tahun 2000 sampai dengan 2010 terlihat kecenderungan penderita penyakit diare naik. Pada tahun 2000 penderita penyakit diare ratarata terjadi pada 301 orang per 1000 penduduk, tahun 2003 naik menjadi 374 orang per 1000 penduduk, tahun 2006 naik menjadi 423 orang per 1000 penduduk dan tahun 2010 menjadi 411 orang per 1000 penduduk [1]. Buku data Ditjen PPM dan PL tahun 2008 menujukkan kejadian luar biasa (KLB) diare sering terjadi, dengan angka CFR masih tinggi [2]. Pada tahun 2008 terjadi KLB diare di 69 kecamatan dengan jumlah kasus 8133 orang, kematian, 239 orang (CFR, 2,94\%). Tahun 2009 terjadi KLB diare di 24 kecamatan dengan jumlah kasus 5.756 orang, dengan kematian 100 orang (CFR 1,74\%) sedangkan tahun 2010 terjadi KLB diare di 33 kecamatan dengan jumlah penderita 4204 dengan kematian 673 orang (CFR 1,74\%). 
Berdasarkan Survei Kesehatan Rumah Tangga (SKRT) tahun 2001, melalui studi mortalitas dan riset kesehatan dasar (Riskesdas) dari tahun ke tahun diketahui bahwa diare masih menjadi penyebab utama kematian di Indonesia [3]. Berdasarkan Riskesdas tahun 2007 prevalensi diare klinis adalah 0,9\%, tertinggi di propinsi Nagaro Aceh Darusalam (18,9\%), dan terendah di propinsi DI Yogyakarta (4,2\%) [1],. Prevalensi diare terbanyak terjadi di pedesaan (10\%) dan perkotaan (7,4\%). Diare cenderung terjadi pada kelompok pendidikan rendah.

Data dari Dinas Kesehatan Palangkaraya Provinsi Kalimantan Tengah, pada periode Januari-Juni 2015 sebesar 17.589 orang menderita penyakit diare, pada periode JanuariDesember 2016 tercatat 15.375 menderita penyakit diare dan kondisi ini hampir merata di seluruh kabupaten atau kota. Kepala Dinas Kesehatan provinsi menduga, bahwa mayoritas berkembangnya penyakit diare mayoritas disebabkan pengaruh musim hujan, lingkungan yang kotor, perilaku hidup bersih dan sehat yang rendah, makan dan minum air yang tercemar. Apa upaya preventif pemerintah untuk mengendalikan kejadian penyakit diare, ditinjau dari segi sanitasi lingkungan?

Diare merupakan penyakit dengan ciri konsistensi feses cair, frekuensi buang air besar meningkat. Diare terjadi pada musim hujan pada umumnya disebabkan karena penurunan kualitas hidup bersih, sehingga meningkatkan perkembangan virus, bakteri dan parasit. Mikroorganisme pathogen biasanya muncul dari saluran drainase yang kotor kemudian mencemari air bersih yang dikonsumsi.

Sesuai Keputusan Menteri Kesehatan No 829/MENKES/SK/VII/2002 bahwa dalam rangka mengoptimalkan kesehatan masyarakat dan upaya mendukung pembangunan kesehatan, diperlukan adanya kebijakan dan langkah strategi yang berkaitan dengan dilaksanakannya kegiatan promosi kesehatan di sektor kesehatan lingkungan [4]. Sehubungan dengan keputusan menteri kesehatan, maka keberadaan sanitasi lingkungan menjadi hal penting dalam siklus pelayanan kesehatan masyarakat. Perlu diperhatikan unsur pelayanan yang bersifat promotif dan preventif selain unsur kuratif.

Sejalan dengan program pelaksanaan pelayanan kesehatan oleh Badan penelitian dan pengembangan kesehatan tahun 2001, bahwa setiap masalah kesehatan pada umumnya disebabkan oleh tiga faktor, yaitu 1) bibit penyakit atau perantara penyebab penyakit, 2) kondisi lingkungan yang mendukung untuk timbulnya penyakit dan 3) kurangnya kesadaran manusia dalam perilaku kesehatan terhadap dirinya sendiri dan lingkungannya [2]. Penyakit bisa timbul dari lingkungan dengan sanitasi buruk. Pengaruh buruknya lingkungan, sebenarnya dapat dicegah dengan mengembangkan kebiasaan hidup sehat dengan melakukan berbagai cara seperti mencuci tangan sebelum dan sesudah makan, membuang sampah pada tempatnya, membersihkan kamar mandi, rumah dan halaman secara rutin. Kebiasaan tersebut dapat memutus siklus pengembangbiakan berbagai jenis organisme penyebab penyakit [5].

Berdasarkan WHO South East Asia Region tahun 1986 pencegahan dan penanggulangan penyakit ada tiga yaitu 1) eliminasi sumber penyakit, 2) melindungi kelompok rentang sakit seperti balita, anak serta dengan memutus mata rantai penularan melalui peningkatan sanitasi lingkungan dan 3) hygiene perorangan [6]. Usaha memutus mata rantai penularan penyakit secara umum dan penyakit diare khususnya seperti yang tercantum pada UNICEF-WHO tahun 2009 [7], maka Direktorat Jendral Pengendalian Penyakit dan Penyehatan Lingkungan Departemen Kesehatan tahun 2006 melakukan kegiatan promosi kesehatan spesifik pada lingkungan dan ekosistem tempat hidup manusia, antara lain [8]:

1. Membudayakan penggunaan air bersih

Risiko menderita diare lebih kecil jika mengkonsumsi air bersih, jika dibandingkan dengan masyarakat yang mengkonsumsi air yang tercemar atau kotor. Tindakan preventif yaitu dengan cara melindungi air dari kontaminasi atau pencemaran, yang dimulai dari sumbernya sampai penyimpanan di rumah. Penting diingat untuk minum air yang sudah matang dan mencuci semua peralatan masak dan peralatan makan dengan air bersih. Black dan rekan menyatakan bahwa penularan kuman infeksius penyebab diare ditularkan melalui fekal oral, artinya kuman tersebut dapat ditularkan 
melalui makanan yang tercemar dengan tinja (melalui jari tangan), wadah makanan dan tempat minum yang dicuci dengan air tercemar [9].

2. Mencuci tangan

Lee dan rekan menyatakan bahwa kebersihan perorangan dapat dilakukan dengan mencuci tangan dengan sabun, terutama setelah buang air besar dan sebelum menyiapkan makanan dapat menurunkan angka kejadian diare sebesar $47 \%$ [10].

3. Menggunakan jamban

Keterangan dari WHO bahwa penggunaan jamban mempunyai dampak yang besar dalam menurunkan risiko terhadap penyakit diare. Setiap keluarga wajib mempunyai jamban untuk buang air besar dan melakukan pembersihan jamban secara teratur, serta gunakan alas kaki jika akan buang air besar sehingga dapat memutuskan siklus rantai diare [6].

4. Penyediaan air bersih

Penyediaan air bersih secara kualitas dan kuantitas harus dijaga, serta menjaga kebersihan diri dan lingkungan mutlak diperlukan, karena beberapa penyakit dapat ditularkan melalui air, antara lain diare, kolera, disentri, hepatitis, penyakit kulit, penyakit mata dan penyakit lainnya [11]. Untuk mencegah terjadinya penyakit tersebut, penyediaan air bersih yang cukup di setiap rumah tangga harus tersedia, di samping itu perilaku hidup bersih harus tetap dilaksanakan.

5. Pengelolaan sampah

Sampah merupakan sumber penyakit dan tempat berkembang biaknya vektor penyakit, seperti lalat, nyamuk, tikus, kecoa. Sampah yang mencemari tanah menimbulkan gangguan kenyamanan dan estetika, seperti bau tidak sedap dan pemandangan yang tidak nyaman untuk dilihat [12]. Pengelolaan sampah sangat penting, tempat sampah harus disediakan dan dibuang ke tempat penampungan sementara. Bila tidak terjangkau oleh pelayanan pembuangan sampah ke tempat pembuangan akhir, maka dapat dilakukan pemusnahan sampah dengan cara ditimbun atau dibakar.

6. Sarana pembuangan air limbah

Potensi penularan penyakit bisa melalui air limbah pabrik atau limbah rumah tangga yang dapat menjadi tempat perindukan nyamuk dan sarang tikus, maka limbah harus dikelola seefisien mungkin, agar tidak menjadi sumber penularan penyakit diare. Namun begitu, sarana pembuangan air limbah yang tidak memenuhi syarat akan menimbulkan bau, mengganggu lingkungan [13].

Prosedur pencarian literatur untuk menjawab pertanyaan di atas dilakukan dengan penelusuran menggunakan pencarian online dengan instrument pencari umum seperti google dan yahoo serta karya ilmiah di perpustakaan. Kata kunci yang digunakan adalah kata kunci berupa penyakit diare, sanitasi, usaha kesehatan masyarakat, pemerintah dan dinas kesehatan, dengan batasan publikasi Bahasa Indonesia atau Inggris.

\section{BAHASAN}

Perubahan perilaku masyarakat untuk lebih peduliterhadap lingkungan membutuhkan kesadaran dan peran dari masyarakat itu sendiri. Perubahan perilaku tidak akan terjadi jika belum muncul kesadaran atas pentingnya sanitasi lingkungan. Untuk menumbuhkan kesadaran ini, pertama kali perlu dilakukan usaha untuk meningkatkan pengetahuan masyarakat tentang perilaku hidup bersih dan sehat terutama sanitasi lingkungan sehingga nantinya dapat mengurangi angka kesakitan diare.

Survei Kesehatan Rumah Tangga Badan Penelitian dan Pengembangan Kesehatan tahun 2003 menunjukkan bahwa untuk mewujudkan promosi kesehatan diatas, maka perlu adanya intervensi melalui program sosialisasi sanitasi lingkungan sedini mungkin, dengan memperkenalkan pengetahuan pentingnya kebersihan air, sanitasi dan higinitas (Water, 
Sanitation and Hygiene) di sekolah [14]. Direktorat jendral Pengendalian Penyakit dan Penyehatan lingkungan memiliki visi jangka panjang dengan mengadakan intervensi sekolah melalui pendidikan sanitasi dan kebersihan di lingkungan sekolah, dengan tujuan meningkatkan pemahaman sanitasi lingkungan secara efektif, sehingga nantinya menurunkan tingkat kejadian penyakit diare sekaligus memajukan kebersihan lingkungan [2]. Kegiatan ini berfokus untuk memberikan lingkungan pembelajaran yang sehat bagi anak berupa sarana dan prasarana sanitasi seperti penggunaan jamban, kebiasaan untuk bersih, adanya pojok cuci tangan maupun penyediaan air bersih. Penting juga stimulasi berupa pemberian keterampilan, sikap dan pengetahuan yang diperlukan untuk praktik kebersihan yang efektif untuk diri dan lingkungan sosialnya, serta mendorong tingkah laku sehat pada generasi yang akan datang.

Menurut Komisi WHO tahun 2001 Program WASH yang efektif mencakup berbagai komponen penting yaitu lingkungan fisik yang sehat, anak sehat dan aktif, petugas sekolah yang terlatih dan berkomitmen serta hubungan keluarga dan masyarakat [15]. UNICEF melaksanakan program WASH secara global di 93 negara.

Adanya kemitraan swasta publik untuk membudayakan cuci tangan dengan sabun. Kajian terkini oleh Black dan rekan menyatakan bahwa cuci tangan dengan sabun menunjukkan hasil positif, dari pada kegiatan mengendalikan vektor perantara penyakit maupun menyediakan air bersih [9]. Terbukti sebesar $42-47 \%$ dari penyakit diare dapat dicegah apabila masyarakat mencuci tangan mereka dengan sabun. Hal positif ini dketahui perusahaan produsen sabun sehingga timbul ide untuk memasarkan "kebahagiaan kebersihan" dan dapat menjadi mitra yang menguntungkan dalam upaya pemerintah untuk meningkatkan kegiatan cuci tangan sampai sekitar 10-20\% [16]

Sanropie menyimpulkan bahwa sumber pathogen diare utama adalah kotoran manusia [17]. Kotoran manusiajuga merupakan sumber penyebab penyakit shigelosis, tipus, kolera, dan diare. Satu gram kotoran manusia dapat mengandung 10 juta virus dan satu juta bakteri. Sedangkan tindakan kedua adalah mencuci tangan setelah bersinggungan dengan kotoran manusia yang merupakan menghambat utama peyebaran penyakit diare. Black dan rekan menyatakan bahwa cuci tangan dengan sabun dapat menurunkan kejadian infeksi sebesar 50\% [9]. Dengan mencuci tangan maka penyebaran zat pembawa penyakit terputus sehingga menurunkan angka kejadian penyakit diare secara signifikan. Survei ekonomi nasional tahun 2004 menyatakan bahwa hanya 50\% anak berusia dibawah 15 tahun yang mencuci tangan dengan sabun dibanding dengan populasi anak yang tinggal di lingkungan perumahan [18].

Menurut WHO tahun 2009, dengan metode promosi kesehatan dalam skala luas maka kegiatan mencuci tangan dengan sabun dapat dianggap sebagai vaksin yang dilakukan oleh diri sendiri, karena dengan mencuci tangan dapat mencegah penyebaran beragam pathogen. Oleh karena itu kegiatan ini jauh lebih efektif daripada penyuntikan vaksin [7]. Mukono mengemukakan bahwa pendekatan kepada masyarakat untuk berhenti buang air besar disembarang tempat dan membangun serta menggunakan jamban yang dikenal dengan gerakan sanitasi total berbasis masyarakat (STBM)/pendekatan sanitasi total (PST) meningkatkan kebersihan air dan sanitasi lingkungan, sehingga dapat memberantas penyakit terutama diare, serta meningkatkan kesehatan ibu dan anak dan menurunkan angka kematian akibat diare [11].

Namun, ada tantangan penggunaan STBM, seperti perlu adanya perubahan sikap dan pola pikir masyarakat untuk mendukung dan mempromosikan sanitasi lingkungan yang benar. Pemerintah bersama masyarakat melalui Permenkes No 416/Menkes/SK/VIII/1990 akan memonitoring dan mengevaluasi kekuatan dan dampak dari kegiatan ini dan memastikan secara cepat status lingkungan yang bebas dari buang air besar secara terbuka [18]. Untuk terwujudnya hal ini dibutuhkan sarana prasarana berupa inovasi dan keberagaman lokal untuk mengembangkan model kakus dengan material lokal dan biaya murah dengan model skema pelaksanaan, pengawasan, penghargaan masyarakat dan hukuman yang sistematis dan terarah. 
Membuang seluruh limbah dari lingkungan rumah tangga membutuhkan adanya pengadaan saluran pembuangan, walaupun sederhana namun tetap efektif dan efisien [5], yang disesuaikan dengan situasi setempat yang rentan terjadi penularan penyakit diare karena sanitasi lingkungan yang buruk, bisa mencakup kota, pedesaan maupun area pinggiran kota dengan kepadatan tinggi, serta area berpenghasilan rendah dan pembangunan rumah baru dengan tata ruang yang lebih umum. Tujuannya berfokus pada melestarikan dan menjaga lingkungan kita agar tetap bersih dan merupakan tindakan mencegah polusi dan yang mencakup pengolahan dan pembuangan air limbah, kendali vektor dan kegiatan pencegahan penyakit lainnya.

Dikenal adanya sanitasi ekologis yang merupakan sebuah sistem daur atau sistem putaran tertutup yan mengolah kotoran manusia sebagai sebuah sumber daya. Menurut KepMenKes RI No 907/Menkes/SK/VII/2002 adanya pendekatan berorientasi pada kesehatan publik dengan pengetahuan bahwa air seni, kotoran manusia dan air merupakan sumber daya dalam putaran ekologis [19]. Sisi positif lain adalah mampu mencegah polusi dan pada saat bersamaan mengembalikan unsur hara ke tanah.

Sanitasi ekologis memiliki aplikasi pada desain toilet serta berbagai macam teknik untuk pengumpulan dan pengolahan air sei dan kotoran manusia baik bentuk kosistensi basah atau kering yang memungkinkan solusi sanitasi yang tepat untuk dikembangkan beragam konteks geografis, politis dan sosioekonomi.

\section{SIMPULAN}

Angka insiden diare berfluktuasi dari tahun ke tahun. Peningkatan penyakit diare berhubungan dengan buruknya sanitasi lingkungan yang akar permasalahannya terdapat pada kurang kesadaran dan pengetahuan pada khususnya masyarakat pedesaan atau wilayah terpencil untuk menjaga dan melestarikan serta melakukan perilaku hidup sehat untuk memutuskan siklus rantai penularan penyakit diare di Indonesia.

Perlu ditingkatkan kerjasama lintas sektoral dan lintas program baik di wilayah daerah, kabupaten maupun provinsi dalam hal pemberian promosi kesehatan yang nantinya akan membantu meningkatkan pengetahuan penduduk sehingga mampu menurunkan angka kejadian penyakit dan kematian akibat penyakit diare.

\section{PUSTAKA ACUAN}

1. Badan penelitian dan pengembangan Kesehatan, Departemen Kesehatan RI.Riset Kesehatan Dasar (Riskesdas) . 2007.

2. Ditjen.PPM\& PL. Departeman Kesehatan RI. Dit.Sepim Kesma.Buku Data 2008

3. Badan penelitian dan pengembangan Kesehatan, Departemen Kesehatan RI.Survei Kesehatan Rumah tangga 2001. Laporan Studi mortalitas 2001: Pola Penyebab Kematian di Indonesia. 2002.

4. Kepmenkes RI No. 829/Menkes/SK/VII/1999 tentang Persyaratan Kesehatan Perumahan. Jakarta : Departemen Kesehatan RI.

5. Magdarina D Agtini, Rooswanti Soeharno, Murad Lesmana, dkk. The burden of diarrhoea, shigellosis, and cholera in North Jakarta, Indonesia: findings from 24 months surveillance. BMC Infectious Diseases 2005, 5:89

6. WHO SEARO (1986) Environmental Health Aspects of Industrial and Residential Area. Regional Health Papers No. 11. New Delhi: WHO Regional Office for South East Asia.

7. UNICEF-WHO. Diarhoea: Why children are still dying and what can be done. 2009 Ditjen.PP \& PL. Departeman Kesehatan RI. Dit.Sepim Kesma. Buku data 2006

8. Ditjen PP dan PL Departemen Kesehatan RI Dit Sepim Kesma. Buyku data 2006

9. Black, R.E., Morris, S.S., and Bryce, J Where and why are 10 million children dying every year? Lancet . 2003, 361: 2226-2234

10. Lee Jong-wook, Director-General, World Health Organization. Water, sanitation and hygiene links to health. Facts and figures updated November 2004 
11. Mukono HJ.(2000). Prinsip dasar Kesehatan Lingkungan. Surabaya: Airlangga University Press, pp 155-157.

12. Kosek, M., Bern, C., and Guerrant, R.L. The global burden of diarrhoeal disease, as estimated from studies published between 1992 and 2000. Bull World Health Organ. 2003, 81: 197204.

13.Parashar, U.D., Hummelman, E.G., Bresee, J.S., Miller, M.A., and Glass, R.I. (2003) Global illness and deaths caused by rotavirus disease in children. Emerg Infect Dis 9: 565-572

14. Badan Litbangkes Dep Kes RI. Susenas 2004.

15. Komisi WHO Mengenai Kesehatan dan Lingkungan. (2001). Planet Kita Kesehatan Kita. Kusnanto H (Editor). Yogyakarta : Gajah Mada University Press, p. 279.Fdfd

16. Napitupulu, MF.(1994). Pelaksanaan Program Penyehatan Lingkungan Pemukiman melalui Pendekatan Kelurahan Demo Kesehatan Lingkungan di DKI Jakarta. Majalah Kesehatan Perkotaan 1:2, 119-128.

17. Sanropie D. (1992). Pedoman Bidang Studi Perencanaan Penyehatan Lingkungan Pemukiman. Jakarta : Departemen Kesehatan R.I.

18. Permenkes No. 416/Menkes/SK/VIII/1990 tentang Pemantauan Kualitas Air Minum, Air Bersih, Air Kolam Renang dan Air Pemandian Umum. Jakarta: Departemen Kesehatan RI. 